$B E S L=Q(1)-1$ indered.

Built-Environment-Sri Lanka -Vol. 04, Issue 01: 2003

\title{
EDITORIAL:
}

\section{Architectural history research - a plea for "place-making"}

In detailing the story of art historians "hijacking" architectural history, Spiro Kostof (1985) points out that in the days gone by, architects themselves studied and wrote architectural history. Modern movement and its outright rejection of historical precedents paved the way for others to step in and interpret architectural history, primarily in terms of its "artistic" aspects. Art Historians, Kostof says, being primarily interested in objects (paintings, sculpture, etc.) reduced architectural history to a linear progression of "styles," grossly neglecting the fact that architecture is about space.

Kostof proposes an agenda for architectural history research by calling for a unified approach that studies the constant interaction between buildings, nature, and their surroundings. He proposes a four-pronged approach towards this goal:

1.Oneness of architecture - treating architecture as a whole, without separating the form from its structure, or facade from form.

2.Setting of architecture - studying architecture in its own settings: both manmade and natural.

3.Community of architecture - every piece of architecture as part of a world-wide community of architecture. Studying architecture in the context of buildings that were contemporary the world over. Also studying the sacred and the grandiose, as well as the humble and the ordinary.

4.Meaning in Architecture- What did a building mean to its people?

Architectural history is a history of making places: This place making action must be studied in the context of its environment. In this way, architects can recover what is peculiar to the history of architecture: a history of places (their environmental and natural qualities as opposed to, say, the history of paintings).

In a further article, Kostof (1990) points out that the conventional separation of architecture and buildings (the "bicycle shed and Lincoln Cathedral" analogy of Nicholas Pevsner) is superficial, and led to the general conclusion among members of the public that architecture is only an aesthetic embellishment of buildings. We need to study both buildings and architecture, the ordinary and the magnificent, in order to show that the contribution architects make is not restricted to ornaments on the facade that can be done without, if so deemed.

Hancock (1982) is also in agreement with this view. He stresses that architects are primarily place-makers and not image-makers. He calls for a study of architectural history in order to draw inspiration to make places in the here and now. Hancock also suggests that this "past" should include the recent past, including modernism and its dethroning of architectural history itself.

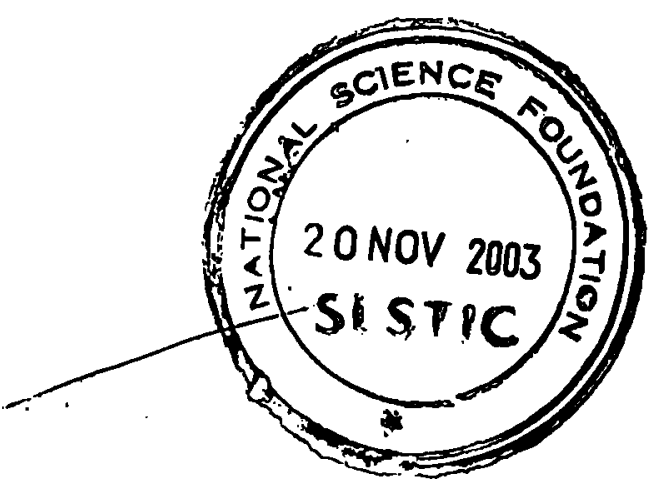


Ackerman (1980) elaborates on the need to structure the study of architectural history as a study of the responses to human experiences, environment, and culture. "Styles" as he points out were never a conscious milieu within which architects in the past operated. He shows that the current divorce between architectural practice and history, has led to practitioners wanting to imitate "styles", relying for information on historians who are primarily concerned with the image of architecture, and not its substance.

In recent years, architects have tended to emphasize the contextual aspects of their design. It is however not necessary for modern designers to contextualize their creations in the light of some superficially understood architectural elements (as post-modernism seems to have done). While it is necessary to place present architecture in a manner that achieves the best fit to its surrounding, architecture also creates its own context. We do not have to reject history in our quest for newer and better forms: neither do we have to conform our designs to elements from history wrongly understood and applied out of place.

It is perhaps fitting then to conclude with a plea made by Norberg-Shulz (1980). Shulz argues for a "theory of place" as the core of architecturathistory research. He shows that such a theory may be arrived at either by analyzing the past structures and abstracting their structural principles (finding pattems?) or by a phenomenological reflection on historical buildings.

There is a crying need to create an architectural history paradigm that deals with place-making rather than image-making. All architecture is history in the sense it already exists. The primary rationale for studying them is to distill their environmental and spatial organization patterns so as to inspire place-making in the here and now. If architects remain true to this vocation, "styles" will follow. Architects' vocation is to facilitate dwelling: everything else is secondary.

\section{References:}

Ackerman, J. S., (1980). "The history of design and the design of history," VIA, 4:13-18.

Hancock, J. E., (1982). "Architecture and its history: past futures and future pasts," J. Architectural Education, 36: 26-33.

Kostof, S., (1985). History of Architecture: Settings and Rituals, New York: Oxford University Press.

Kostof, S., (1990). "Culture and the built form: the limits of architectural history," (unpublished manuscript).

Norberg-Shulz, C., (1980). "History and the language of architecture," in Hancock, J.E., (ed.), History in, of, and for Architecture, Cincinnati: University of Cincinnati Press, pp. 6-15. 